\title{
Acidolysis of terebinth fruit oil with palmitic and caprylic acids in a recirculating packed bed reactor: optimization using response surface methodology
}

\author{
D. Koçak Yanık ${ }^{\bowtie}$, H. Keskin, S. Fadıloğlu and F. Göğüş \\ Department of Food Engineering, Faculty of Engineering, University of Gaziantep, 27310 Gaziantep, Turkey \\ ${ }^{\otimes}$ Corresponding author: dkocak@gantep.edu.tr
}

Submitted: 15 June 2015; Accepted: 23 November 2015

SUMMARY: The acidolysis reaction of terebinth fruit oil with caprylic and palmitic acid has been investigated. The reaction was catalyzed by lipase (Lipozyme IM from Rhizomucormiehei) and carried out in recirculating packed bed reactor. The effects of reaction parameters have been analyzed using response surface methodology. Reaction time (3.5-6.5 h), enzyme load (10-20\%), substrate flow rate $\left(4-8 \mathrm{~mL} \cdot \mathrm{min}^{-1}\right)$ and substrate mole ratios (Terebinth oil : Palmitic acid : Caprylic acid, 1:1.83:1.22-1:3.07:2.05) were evaluated. The optimum reaction conditions were $5.9 \mathrm{~h}$ reaction time, $10 \%$ enzyme load, $4 \mathrm{~mL} \cdot \mathrm{min}^{-1}$ substrate flow rate and 1:3.10:2.07 substrate mole ratio. The structured lipid obtained at these optimum conditions had $52.23 \%$ desired triacylglycerols and a lower caloric value than that of terebinth fruit oil. The melting characteristics and microstructure of the structured lipid were similar to those of commercial margarine fat extracts. The results showed that the structured lipid had the highest oxidative stability among the studied fats.

KEYWORDS: Caprylic acid; Palmitic acid; Pistaciaterebinthus L.; Response surface methodology; Structured lipid

RESUMEN: Acidolisis de aceite de pistacho con los ácidos palmítico y caprílico en un reactor de recirculación de lecho compacto: optimización mediante metodología de superficie de respuesta. Se ha investigado la reacción de acidolisis del aceite de pistacho con los ácidoscaprílico y palmítico. La reacción fue catalizada por la lipasa Lipozyme IM de Rhizomucormiehei y realizada mediante recirculación del reactor de lecho compacto. Los efectos de los parámetros de la reacción han sido analizados mediante el uso de la metodología de superficie de respuesta. El tiempo de reacción (3.5 hasta 6.5 h), la carga de enzima (10-20\%), el caudal de sustrato (4-8 $\mathrm{mL} \cdot \mathrm{min}^{-1}$ ) relaciones molares de los sustrato (aceite de pistacho: ácido palmítico: ácido caprílico, 1: 1,83: 1,22-1: 3,07: 2,05) fueron evaluados. Las condiciones óptimas de reacción fueron 5,9 h de tiempo de reacción, el 10\% de carga de la enzima, $4 \mathrm{~mL} \cdot \mathrm{min}^{-1}$ de caudal de sustrato y 1: 3,10: 2,07 de relación molar de sustratos. Los lípidos estructurados obtenidos en las condiciones óptimas tenías 52,23\% de triacilgliceroles deseados y un valor calórico menor que la de encina aceite de la fruta. Características de fusión y microestructura de lípido estructurado fueron similares a las de los extractos de grasa margarina comerciales. Los resultados mostraron que el lípido estructurado tenía una estabilidad oxidativa más alta entre las grasas estudiadas.

PALABRAS CLAVE: Ácido caprílico; Ácido palmítico; Lípido estructurado; Metodología de superficie de respuesta; Pistaciaterebinthus $L$.

Citation/Cómo citar este artículo: Koçak Yanık D, Keskin H, Fadıloğlu S, Göğüş F. 2016. Acidolysis of terebinth fruit oil with palmitic and caprylic acids in a recirculating packed bed reactor: optimization using response surface methodology. Grasas Aceites 67 (2): e131. doi: http://dx.doi.org/10.3989/gya.0633152.

Copyright: (C) 2016 CSIC. This is an open-access article distributed under the terms of the Creative Commons Attribution-Non Commercial (by-nc) Spain 3.0 Licence. 


\section{INTRODUCTION}

Most native fats and oils have different functional and physical properties, metabolic fate and health benefits due to their component fatty acid (FA) residues and the distribution of them on the glycerol backbone of triacylglycerols (TAG) (Khodadadi et al., 2013). Fats and oils have limited applications in their unmodified forms and several technologies have been developed to modify them for beneficial end-usage. SLs are a main class of modified lipids that can be obtained either chemically or enzymatically (Osborn and Akoh, 2002). The enzymatic process is the most favorable technique because of enzyme selectivity, mild reaction conditions and ease of product recovery (Yang et al., 2003). Enzymatic acidolysis reactions can be performed in various systems such as batch-type or packed bed reactors (PBR) but packed bed reactors seem to be more suitable with a relatively short reaction time and reduced enzyme loss due to the absence of collisions between enzyme particles and an impeller (Zhao et al., 2012).

Pistaciaterebinthus L. is one of the 20 Pistacia species widely distributed in the Mediterranean region and Asia (Topçu et al., 2007). The fruit of Pistaciaterebinthus L. is an oil rich seed. This oily seed has $40-60 \%$ crude oil which is rich in oleic acid $(52.3 \%)$ followed by palmitic $(21.3 \%)$ and linoleic (19.7\%) acids (Özcan, 2004; Agar et al., 1995). The major constituents of $s n$-2 fatty acids of this oil are oleic $(67.0 \%)$ and linoleic $(23.6 \%)$ acids (Koçak et al., 2011). Therefore it can be considered as a promising substrate for the synthesis of structured lipids.

Terebinth fruit oil (TO) could be utilized by keeping its oleic acid in its orginal position and substituting the other fatty acids with caprylic and palmitic acids to produce a low calory and spreadable SL. The aim of the present study was to investigate and optimize the lipase-catalyzed acidolysis reaction conditions for the packed bed reactor system using response surface methodology to synthesize the targeted SL.

\section{MATERIALS AND METHODS}

\subsection{Materials}

Palmitic acid (purity $\geq 98.0 \%$ ), caprylic acid (purity $\geq 99.0 \%$ ) and some TAG standards; triolein (OOO), tripalmitin(PPP), trilinolein(LLL), 1, 2-olein3-palmitin (OOP), 1,3-palmitin-2-olein (POP), 1,2-linolein-3-palmitin (LLP), 1,2-linolein-3-olein (LLO) were purchased from Sigma-Aldrich (St. Louis, MO). Other TAG standards; 1,3-caprylin2-olein (COC), 1-palmitin-2-olein-3-caprylin (POC), 1,3-caprylin-2-linolein (CLC), 1-caprylin-2,3-olein (COO), 1-palmitin-2-linolein-3-caprylin (PLC) and 1-caprylin-2,3-linolein (CLL), were produced in the laboratory. Immobilized $s n-1,3$ specific lipase
(Lipozyme IM, immobilized from Rhizomucormiehei, $140 \mathrm{U} / \mathrm{g}$ ), acetone, acetonitrile, $n$-hexane, silica gel (SG 60, 70-230 mesh) and Supelco ${ }^{\circledR} 37$ FAME Mixture component were also purchased from Sigma-Aldrich (St. Louis, MO). All solvents used were of HPLC grade. All other reagents and solvents were of analytical or chromatographic grade. Soft and hard margarine samples were purchased from the supermarket in Gaziantep.

\subsection{Extraction of Terebinth fruit oil}

Terebinth fruits were harvested from Yamaçoba village near Gaziantep, Turkey, in September 2009. Terebinth fruit oil was extracted by cold pressing. The oil obtained was $35 \mathrm{~g}$ per $100 \mathrm{~g}$ terebinth fruit (M.C: $5.7 \%(\mathrm{w} \mathrm{b}))$. The fine particles found in the pressed oil were removed by centrifugation and stored at $-20^{\circ} \mathrm{C}$ until analysis. Details are described in a previous publication (Koçak et al., 2013).

\subsection{Acidolysis reaction}

Acidolysis reactions were carried out on a laboratory scale packed-bed reactor similar to the system of Çiftçi et al., (2009a). A jacketed glass column (Ildam, Ankara, Turkey) was used as enzyme bed (i.d. $10 \mathrm{~mm} \times$ length $100 \mathrm{~mm}$ ). The column was packed with a specified amount of Lipozyme IM and the upper and the lower ends of the column were layered with glass wool. The bed porosity was calculated according to $\mathrm{Xu}$ et al., (1998) and found to be 0.46 . Terebinth fruit oil ( $1 \mathrm{mmol}, \mathrm{MW}: 864)$ and the correspondent ratio of caprylic and palmitic acids were mixed in $100 \mathrm{~mL}$ of $n$-hexane to prepare the reaction mixture. Then it was pumped upward into the column using a peristaltic pump (Watson Marlow Bredel, model 505U, Falmouth, UK). The bioreactor was operated at a product re-circulation mode. The system temperature was maintained at $45^{\circ} \mathrm{C}$ by a circulating water bath. The temperature of the reaction mixture in the substrate reservoir was pre-heated to the reaction temperature and also maintained at that temperature during the reaction on a hot plate/stirrer. This optimized reaction temperature was based on a previous study (Koçak et al., 2011). A new enzyme bed was used for each experimental point. At the end of the reaction $n$-hexane was immediately evaporated in a rotary vacuum evaporator and the mixtures were stored at $-20^{\circ} \mathrm{C}$ for subsequent analysis. All reactions were performed in triplicate and average values are reported.

\subsection{Experimental design and optimization by response surface methodology}

A five-level, four factorial central composite rotatable design (CCRD) was employed to study the response patterns and to determine the optimum 
TABLE 1. Treatment schedule for four-variable five-level CCRD and experimental data for the acidolysis of terebinth fruit oil with caprylic and palmitic acids

\begin{tabular}{|c|c|c|c|c|c|c|c|c|}
\hline \multirow[b]{2}{*}{ No } & \multicolumn{3}{|c|}{ Factors } & \multirow[b]{2}{*}{$\mathbf{T i}^{\mathrm{d}}$} & \multirow{2}{*}{$\begin{array}{c}\text { Total Produced } \\
\text { TAGs \% } \\
\end{array}$} & \multirow[b]{2}{*}{ Desired TAGs \% } & \multirow[b]{2}{*}{$\operatorname{Energy~}\left(\mathbf{k j} \cdot \mathrm{g}^{-1}\right)$} & \multirow{2}{*}{$\begin{array}{l}\% \text { Solid fat by } \\
\text { DSC at } 25^{\circ} \mathbf{C}\end{array}$} \\
\hline & $\mathbf{S b}^{\mathbf{a}}$ & $\mathbf{E n}^{\mathrm{b}}$ & $\mathbf{Q}^{\mathbf{c}}$ & & & & & \\
\hline 1 & 1.23 & 10 & 4 & 3.5 & $39.99 \pm 0.17^{\mathrm{e}}$ & $33.99 \pm 0.14$ & $39.10 \pm 0.01$ & $2.11 \pm 0.06$ \\
\hline 2 & 2.08 & 10 & 4 & 3.5 & $54.08 \pm 0.32$ & $48.22 \pm 0.28$ & $38.96 \pm 0.03$ & $6.01 \pm 0.12$ \\
\hline 3 & 1.23 & 20 & 4 & 3.5 & $46.16 \pm 0.26$ & $39.05 \pm 0.17$ & $39.10 \pm 0.01$ & $5.17 \pm 0.26$ \\
\hline 4 & 2.08 & 20 & 4 & 3.5 & $57.84 \pm 0.27$ & $51.02 \pm 0.37$ & $38.96 \pm 0.01$ & $11.17 \pm 0.35$ \\
\hline 5 & 1.23 & 10 & 8 & 3.5 & $37.69 \pm 0.15$ & $30.43 \pm 0.43$ & $39.16 \pm 0.03$ & $1.87 \pm 0.47$ \\
\hline 6 & 2.08 & 10 & 8 & 3.5 & $50.55 \pm 0.43$ & $44.10 \pm 0.32$ & $39.04 \pm 0.02$ & $6.84 \pm 0.52$ \\
\hline 7 & 1.23 & 20 & 8 & 3.5 & $49.37 \pm 0.38$ & $43.10 \pm 0.23$ & $39.05 \pm 0.01$ & $6.15 \pm 0.38$ \\
\hline 8 & 2.08 & 20 & 8 & 3.5 & $60.52 \pm 0.62$ & $54.15 \pm 0.41$ & $38.91 \pm 0.01$ & $10.77 \pm 0.42$ \\
\hline 9 & 1.23 & 10 & 4 & 6.5 & - & - & - & - \\
\hline 10 & 2.08 & 10 & 4 & 6.5 & $60.18 \pm 0.42$ & $51.92 \pm 0.12$ & $38.91 \pm 0.01$ & $15.05 \pm 0.25$ \\
\hline 11 & 1.23 & 20 & 4 & 6.5 & $52.74 \pm 0.21$ & $43.57 \pm 0.25$ & $39.00 \pm 0.02$ & $10.92 \pm 0.13$ \\
\hline 12 & 2.08 & 20 & 4 & 6.5 & $61.90 \pm 0.35$ & $52.88 \pm 0.27$ & $38.93 \pm 0.02$ & $21.34 \pm 0.28$ \\
\hline 13 & 1.23 & 10 & 8 & 6.5 & $47.17 \pm 0.37$ & $39.48 \pm 0.38$ & $39.06 \pm 0.01$ & $5.57 \pm 0.12$ \\
\hline 14 & 2.08 & 10 & 8 & 6.5 & $59.65 \pm 0.53$ & $51.71 \pm 0.19$ & $38.93 \pm 0.01$ & $15.23 \pm 0.22$ \\
\hline 15 & 1.23 & 20 & 8 & 6.5 & $53.21 \pm 0.19$ & $43.46 \pm 0.13$ & $38.97 \pm 0.01$ & $12.03 \pm 0.33$ \\
\hline 16 & 2.08 & 20 & 8 & 6.5 & $62.38 \pm 0.65$ & $52.73 \pm 0.35$ & $38.86 \pm 0.01$ & $18.15 \pm 0.42$ \\
\hline 17 & 0.80 & 15 & 6 & 5.0 & $41.66 \pm 0.15$ & $32.90 \pm 0.09$ & $39.10 \pm 0.01$ & $5.20 \pm 0.18$ \\
\hline 18 & 2.50 & 15 & 6 & 5.0 & $63.46 \pm 0.28$ & $56.90 \pm 0.42$ & $38.87 \pm 0.01$ & $13.82 \pm 0.70$ \\
\hline 19 & 1.65 & 5 & 6 & 5.0 & $46.23 \pm 0.42$ & $39.12 \pm 0.20$ & $39.05 \pm 0.02$ & $4.69 \pm 0.35$ \\
\hline 20 & 1.65 & 25 & 6 & 5.0 & $58.60 \pm 0.35$ & $49.50 \pm 0.28$ & $38.90 \pm 0.01$ & $13.84 \pm 0.28$ \\
\hline 21 & 1.65 & 15 & 2 & 5.0 & $52.59 \pm 0.10$ & $46.59 \pm 0.52$ & $39.08 \pm 0.03$ & $12.19 \pm 0.51$ \\
\hline 22 & 1.65 & 15 & 10 & 5.0 & $57.17 \pm 0.23$ & $47.97 \pm 0.11$ & $38.93 \pm 0.01$ & $13.12 \pm 0.32$ \\
\hline 23 & 1.65 & 15 & 6 & 2.0 & $42.00 \pm 0.08$ & $34.90 \pm 0.14$ & $39.11 \pm 0.01$ & $2.81 \pm 0.25$ \\
\hline 24 & 1.65 & 15 & 6 & 8.0 & $52.01 \pm 0.45$ & $46.33 \pm 0.05$ & $39.23 \pm 0.01$ & $22.97 \pm 0.32$ \\
\hline 25 & 1.65 & 15 & 6 & 5.0 & $52.40 \pm 0.27$ & $45.62 \pm 0.33$ & $39.07 \pm 0.01$ & $9.42 \pm 0.07$ \\
\hline 26 & 1.65 & 15 & 6 & 5.0 & $51.63 \pm 0.58$ & $44.30 \pm 0.47$ & $39.01 \pm 0.02$ & $5.46 \pm 0.48$ \\
\hline 27 & 1.65 & 15 & 6 & 5.0 & $52.20 \pm 0.43$ & $44.30 \pm 0.26$ & $39.04 \pm 0.00$ & $6.72 \pm 0.37$ \\
\hline 28 & 1.65 & 15 & 6 & 5.0 & $51.00 \pm 0.10$ & $44.12 \pm 0.38$ & $39.05 \pm 0.01$ & $8.30 \pm 0.39$ \\
\hline 29 & 1.65 & 15 & 6 & 5.0 & $52.70 \pm 0.29$ & $45.30 \pm 0.22$ & $39.06 \pm 0.00$ & $7.20 \pm 0.42$ \\
\hline 30 & 1.65 & 15 & 6 & 5.0 & $51.17 \pm 0.23$ & $45.80 \pm 0.37$ & $39.00 \pm 0.02$ & $7.70 \pm 0.17$ \\
\hline
\end{tabular}

${ }^{\mathrm{a}}$ Substrate ratio (mol/mol; Terebinth oil : Fatty acids, 1:1.22-2.07); ${ }^{\mathrm{b}}$ Enzyme load (wt.\%, based on the amount of substrates); ${ }^{\mathrm{C}}$ Substrate flow rate $\left(\mathrm{mL} \cdot \mathrm{min}^{-1}\right) ;{ }^{\mathrm{d}}$ Reaction time $(\mathrm{h}) ;{ }^{\mathrm{e}}$ Mean $\pm \mathrm{SD}, \mathrm{n}=3$

combination of variables. CCRD was composed of 30 experiments consisting of 16 axial points, 8 star points, 6 center points (Table 1). The star points provide an estimation of curvature of the models. Six replicate runs at the center point of the design were performed to allow for the estimation of pure error. 
All 30 runs were performed in a totally random order to avoid bias.

The independent variables and their levels selected were as follows: reaction time (Ti; 3.5-6.5 h), enzyme load (En; 10.0-20.0\%), substrate flow rate $\left(\mathrm{Q} ; 4-8 \mathrm{~mL} \cdot \mathrm{min}^{-1}\right)$ and substrate mole ratios (Sb; TO:FA, 1:1.23-2.08). Although the substrate mole ratio of TO:FA varied from 1:1.23 to $1: 2.08$, the mole ratio of TO:PA:CA in the reaction mixtures varied from 1:1.85:1.23 to 1:3.12:2.08 due to the ratio of PA:CA which was fixed as 1.5:1 from preliminary studies. These upper and lower limits of substrate ratio were generated by response surface methodology design according to the defined star point. The minimum star point for substrate mole ratio was chosen as 0.8 to prevent the limiting substrate mole ratio of 2.0. In that case, the minimum mole ratio of TO:PA:CA was 1:1.2:0.8 and the available substrate were 2.0 moles to bind in place of cleaved fatty acids.

The experimental data obtained were fitted to a quadratic response surface model equation:

$$
Y_{1,2}=\beta_{0}+\sum_{i=1}^{4} \beta_{i} X_{i}+\sum_{i=1}^{4} \beta_{i i} X_{i}^{2}+\sum_{i=1}^{3} \sum_{j=i+1}^{4} \beta_{i j} X_{i} X_{j}+\varepsilon
$$

where $Y_{1}$ is the response for weight percent of total produced TAG (CLC, COC, CLL, COL, PLC, COO, POC, OLLn, PLP, POP, PPP), $\mathrm{Y}_{2}$ is the response for the weight percent of the desired TAG (POP, POC, COC, CLC, PLP, PLC, PPP). $\beta_{0,} \beta_{i,} \beta_{i i} \beta_{i j}$ were constant coefficients of intercept, linear, quadratic and interaction terms, respectively, $\mathrm{x}_{i}$ and $\mathrm{x}_{j}$ are independent variables and $\varepsilon$ is the random error. The first- or second-order coefficients were generated by regression analysis with backward elimination.

The data from the experiments performed were analyzed using RSM (Stat-Ease, Design-Expert software, version 7). ANOVA, regression analysis, and model generation were used to evaluate the effects of factors and to optimize reaction conditions. The level of significance for the model was set at $99 \%$ confidence level and all other tests were set at $95 \%$ confidence level. The goodness of the models established were determined using the coefficient of determination, $\mathrm{R}^{2}$, together with the absolute average deviation values and ANOVA (Arifin et al., 2012).

\subsection{Isolation of TAG}

The produced TAG was isolated in two steps. Firstly, the mixture obtained from the reaction was neutralized to remove free fatty acids by using the similar method as Çiftçi (2009b). Then, the TAG of the neutralized product was separated from monoacylglycerols and diacylglycerols by mini column chromatography on silica gel (SG 60, 70-230 mesh,
Merck). $0.5-1 \mathrm{~g}$ of neutralized product was dissolved in $8 \mathrm{ml}$ of elution solvent (light petroleum ether/diethyl ether, 90:10, v/v) and eluted through the mini silica column with elution solvent. Then the purified reaction product was obtained by evaporating the solvent (Dobarganes et al., 2000).

\subsection{Analysis of TAG content}

The TAG composition of the reaction product was determined by reversed phase HPLC using the method proposed by the AOCS Official Method Ce 5b-89 (AOCS 1993). Analyses were carried out isocratically with a mobile phase consisting of 64:36 (v/v) acetone/acetonitrile. The oil was diluted in acetone, filtered and auto-injected into the column (Supelcosil LC-18-DB, $5 \mu \mathrm{m}, 250 \times 4.6 \mathrm{~mm}$; Supelco, USA) with an accompanying guard column (Supelguard LC-18-DB, Supelco, USA). It was eluted at a flow rate of $1.0 \mathrm{~mL} \cdot \mathrm{min}^{-1}$. The column temperature was set at $30{ }^{\circ} \mathrm{C}$ and the elution was monitored with a Schimadzu LC RID-10A refractive index detector. The total analysis time was 36 min. All triacylglycerol contents were expressed as weight percent of the total weight of the sample. All analyses were performed in triplicate, and average values were reported. Peak identification was performed by comparing the retention times of sample TAG with those of TAG standards. Since there are no standards available for some new synthesized TAG, these were produced and isolated in the laboratory and were used in peak identification.

\subsection{Analysis of fatty acid composition}

The fatty acid composition of the samples was determined after converting fatty acids into corresponding fatty acid methyl esters (FAME). After methylation the fatty acid composition was determined with a Shimadzu GC17A gas chromatograph equipped with a flame ionization detector and a BPX capillary column $(30 \mathrm{~m} \times 0.22 \mathrm{~mm}$ id $\times 0.25 \mu \mathrm{m}$ film thickness). The temperatures of the injector and detector were set at 225 and $250^{\circ} \mathrm{C}$, respectively. The oven was heated to $60{ }^{\circ} \mathrm{C}$ for $1 \mathrm{~min}$, then the temperature was increased to $170{ }^{\circ} \mathrm{C}$ at a rate of $10^{\circ} \mathrm{C} \cdot \mathrm{min}^{-1}$ and then from 170 to $230^{\circ} \mathrm{C}$ at a rate of $3{ }^{\circ} \mathrm{C} \cdot \mathrm{min}^{-1}$ and held at this temperature for $15 \mathrm{~min}$. Nitrogen was used as the carrier gas, flowing at a rate of $1 \mathrm{~mL} \cdot \mathrm{min}^{-1}$. FAME were identified by comparison with relative retention times of standard mixtures.

\subsection{Separation of the fat phase of margarine}

$10-15 \mathrm{~g}$ margarine were incubated at $55^{\circ} \mathrm{C}$ for $40 \mathrm{~min}$ in a separatory funnel. The upper phase was washed twice with warm water and sodium sulphate was used to remove the water. The upper phase was 
separated and used in differential scanning calorimetry (DSC) analysis.

\subsection{Determination of percent of solid fat by DSC}

The percentages of solids of margarine fats and structured lipids were analyzed by DSC (Perkin Elmer DSC-6, Norwalk, CN, USA). The DSC instrument was calibrated with indium (m.p. $156.6^{\circ} \mathrm{C}$, $\left.\Delta \mathrm{Hf}=28.45 \mathrm{~J} \cdot \mathrm{g}^{-1}\right)$. Nitrogen was used as purge gas at a flow of $40 \mathrm{~mL} \cdot \mathrm{min}^{-\mathrm{P}}$. A sample was completely melted at $80^{\circ} \mathrm{C}$ before being weighed (5-10 mg) into an aluminum pan which was then sealed. An empty, hermetically sealed aluminum pan was used as reference. The previous thermal history of the sample was erased by heating the sample to $80^{\circ} \mathrm{C}$ in the DSC instrument and holding it for $10 \mathrm{~min}$. The sample was then cooled to $-60^{\circ} \mathrm{C}$ at a rate of $5^{\circ} \mathrm{C} \cdot \mathrm{min}^{-1}$ and held at $-60{ }^{\circ} \mathrm{C}$ for $10 \mathrm{~min}$. At the end of the cooling period, the sample was heated at $5{ }^{\circ} \mathrm{C} \cdot \mathrm{min}^{-1}$ to $80^{\circ} \mathrm{C}$. The $\%$ of solids was calculated at various temperatures from the DSC heating thermogram data by partial integration according to Tieko and Aparecida (1995). All DSC values reported are the average of two scans.

\subsection{Determination of caloric value of structured lipids}

The theoretical energy values of TO and the produced SL were calculated using the approach of Livesey (1984). First, the energy values for the FA were calculated using the method proposed by Taguchi et al.,(2001). Then the heat of combustion of each fatty acid was used to calculate the heat of combustion of each produced TAG. The details are described in a previous study (Koçak et al., 2013).

\subsection{Microstructure}

The microstructure of the SL, terebinth fruit oil and the separated fat phase of commercially available margarines were examined using a polarized light microscope (Olympus BX51, Olympus Optical Co., Ltd., Tokyo, Japan) equipped with a Pixera color video camera (model PVC 100C, Los Gatos, CA, USA). A crystallization method similar to the method of Ahmadi et al., (2008) was used. Samples were molten at $80^{\circ} \mathrm{C}$ for $15 \mathrm{~min}$ in order to erase the crystal memory and $20 \mu \mathrm{L}$ of sample were placed on a glass microscope slide which was heated to the same temperature. A cover slip at the same temperature of the sample was then gently laid over the fat drop to remove air and spread the fat. The samples were then allowed to crystallize for 48 $\mathrm{h}$ at room temperature $\left(22-24^{\circ} \mathrm{C}\right)$. Images were captured under polarized light with 40X magnification on the gray-scale.

\subsection{Oxidative Stability}

The oxidative stability of the samples was determined by a Perkin Elmer differential scanning calorimeter (DSC-6, Norwalk, Conn., U.S.A.). The instrument was calibrated with an indium standard. Fat samples of $5 \pm 0.5 \mathrm{mg}$ were weighed into open aluminum pans, with an empty pan as reference, and placed in the sample chamber of the DSC. The isothermal temperature program was programmed at $140{ }^{\circ} \mathrm{C}$ and oxygen was passed through the sample chamber at a flow rate of $100 \mathrm{~mL} \cdot \mathrm{min}^{-1}$ at atmospheric pressure. Similar to Tan et al., (2002) the oxidation induction time of the oxidation reaction was determined by taking the time value corresponding closely to the intersection of the extrapolated baseline and the tangent line of the exotherm.

\subsection{Determination of lipase reusability}

The re-usability of Lipozyme IM from Rhizomucormiehei in the acidolysis of TO with $\mathrm{CA}$ and PA in the PBR system was studied at optimimum conditions (Sb: 2.07 , En: 10.0\%, Q: $4 \mathrm{~mL} \cdot \mathrm{min}^{-1}$, Ti: 5.9 h). After completion of each reaction, the enzyme bed was washed with five times the enzyme bed volume of fresh hexane and re-used for the next reaction. The relative activity of then enzyme was monitored according to the amount of desired TAG with repeated use of the lipase. There was negligible loss in lipase activity even after repeated use for 10 times. The lipase activity was well maintained $(97 \%)$ in repeated cycles.

\subsection{Statistical Analysis}

Solid fat content comparisons for the produced SL and commercially available margarines were made using one-way analysis of variance. Duncan's test for multiple comparisons was used for all post hoc analyses. $\mathrm{P}<0.05$ was considered significant. The SPSS Statics 15.0, version 2.0 (2006), (SPSS Inc., Chicago) was used.

\section{RESULTS AND DISCUSSION}

\subsection{Model fitting}

Response surface methodology was implemented to model the three responses; total produced TAG $(\%)$, desired TAG $(\%)$ and energy $\left(\mathrm{kj}^{-1} \mathrm{~g}^{-1}\right)$. The total produced TAGs were the sum of all the TAGs which were synthesized by the acidolysis reaction. The desired TAGs were the targeted TAGs produced by the incorporation of both palmitic and caprylic acid into the $s n-1,3$ position of the original TAG species of terebinth oil. The experimental data were best fit to quadratic models using multiple regression analysis. 
Insignificant factors and interactions were eliminated by backward elimination in the models. Even if some linear, quadratic or interaction terms were statistically insignificant, they were not eliminated by backward elimination to maintain the hierarchy of the model. The presence of insignificant terms in Table 2 was the reason for this elimination principle. The models predicted for all responses were significant at the $99 \%$ confidence level and showed statistically insignificant $(\mathrm{P}<0.05)$ lack of fit with high coefficients of determinations between 0.92 and 0.98 .

\subsection{Effects of reaction parameters}

Table 2 shows the coefficients and $P$-values for both total produced TAG ( $\%)$ and desired TAG $(\%)$. According to the results of the statistical analysis, the enzyme load, time and substrate mole ratio were statistically significant $(\mathrm{P}<0.0001)$ and had a positive effect on these responses. However, the substrate flow rate was not significantly effective. Substrate mole ratio had the most significant effect while the other variables had a relatively small effect. The results found by Arifin et al., (2012); Xu et al., (2000); Hamam and Budge (2010) were in agreement with these findings.

The interaction terms of $\mathrm{Sb}^{*} \mathrm{En}, \mathrm{En} * \mathrm{Q}$ and En*Ti were found significantly effective on total produced TAG (\%). The Sb*En and En*Ti interactions had a negative effect on the total produced TAG while the En*Q had a positive effect. On the other hand, En*Ti and En*Q were also significant on the synthesis of the desired TAG. En*Ti had a negative effect on the synthesis of desired TAG, whereas the interaction between En*Q had a positive effect. Moreover, the second orders of substrate flow rate and time were found significant on both total produced TAG $(\%)$ and desired TAG $(\%)$. The negative coefficient of second order for time implies that this variable had an optimum value within the studied range.

To evaluate the effects of the experimental factors on responses, three dimensional response surface plots were constructed by varying two factors and keeping others at their center points. Figures 1 and 2 show the effects of the experimental factors on total produced TAG $(\%)$ and desired TAG $(\%)$, respectively. The trends of all response surface plots were in parallel with the results of the model coefficients. It was seen that increasing enzyme load, substrate mole ratio and time improved the incorporation of fatty acids and production of desired TAG (\%). As estimated in the models, the incorporation of fatty acids increased with increasing time until the reaction reached equilibrium at around 6 hours.

Figures1 (b) and (c) illustrate the effects of interactions for $\mathrm{En} * \mathrm{Sb}$ and $\mathrm{En} * \mathrm{Ti}$ on total produced TAG $(\%)$, respectively. The increase in $\mathrm{Sb}$, En and $\mathrm{Ti}$ individually caused an increase in the incorporation of fatty acids while a decreasing effect was observed when their interactions were considered. Figure 1d shows the positive effect of substrate flow rate when its interaction with the enzyme load was considered or vice versa. However, the substrate flow rate was not found significantly effective by itself on total produced TAG $(\%)$.

TABLE 2. Estimated coefficient for the fit second order polynomial representing the relationship between the response and process variables

\begin{tabular}{|c|c|c|c|c|c|c|c|}
\hline \multirow[b]{2}{*}{ Variables } & \multicolumn{3}{|c|}{ Total Produced TAGs* } & \multicolumn{4}{|c|}{ Desired TAGs** } \\
\hline & $\begin{array}{l}\text { Estimated } \\
\text { coefficients }\end{array}$ & $\begin{array}{l}\text { Standard } \\
\text { error }\end{array}$ & $\begin{array}{l}P \text {-value } \\
\text { Prob }>\text { F }\end{array}$ & Variables & $\begin{array}{l}\text { Estimated } \\
\text { coefficients }\end{array}$ & Standard error & $\begin{array}{l}P \text {-value } \\
\text { Prob }>\text { F }\end{array}$ \\
\hline $\begin{array}{l}\text { Substrate mole } \\
\text { ratio }(\mathrm{Sb})\end{array}$ & 5.735 & 0.260 & $<0.0001^{\mathrm{a}}$ & $\begin{array}{l}\text { Substrate mole ratio } \\
(\mathrm{Sb})\end{array}$ & 5.853 & 0.243 & $<0.0001^{\mathrm{a}}$ \\
\hline $\begin{array}{l}\text { Enzyme Load } \\
\% \text { (En) }\end{array}$ & 3.033 & 0.260 & $<0.0001^{\mathrm{a}}$ & Enzyme Load \% (En) & 2.488 & 0.243 & $<0.0001^{\mathrm{a}}$ \\
\hline $\begin{array}{l}\text { Substrate flow } \\
\text { rate }(\mathrm{Q})\end{array}$ & 0.419 & 0.260 & $0.1244^{\mathrm{b}}$ & Substrate flow rate $(\mathrm{Q})$ & 0.004 & 0.243 & $0.9860^{\mathrm{b}}$ \\
\hline $\begin{array}{l}\text { Reaction time } \\
\text { (Ti) }\end{array}$ & 2.826 & 0.260 & $<0.0001^{\mathrm{a}}$ & Reaction time (Ti) & 2.321 & 0.243 & $<0.0001^{\mathrm{a}}$ \\
\hline $\mathrm{Sb}^{*} \mathrm{En}$ & -0.732 & 0.324 & $0.0360^{\mathrm{c}}$ & $\mathrm{Sb}^{*} \mathrm{En}$ & -0.579 & 0.303 & $0.0725^{\mathrm{b}}$ \\
\hline $\mathrm{En} * \mathrm{Q}$ & 0.798 & 0.324 & $0.0236^{\mathrm{c}}$ & $\mathrm{Sb}^{*} \mathrm{Ti}$ & -0.585 & 0.303 & $0.0698^{\mathrm{b}}$ \\
\hline $\mathrm{En} * \mathrm{Ti}$ & -0.945 & 0.324 & $0.0089^{\mathrm{d}}$ & $\mathrm{En} * \mathrm{Q}$ & 1.033 & 0.303 & $0.0032^{\mathrm{d}}$ \\
\hline$Q^{2}$ & 0.817 & 0.232 & $0.0023^{\mathrm{d}}$ & $\mathrm{En} * \mathrm{Ti}$ & -1.389 & 0.303 & $0.0002^{\mathrm{a}}$ \\
\hline \multirow[t]{2}{*}{$\mathrm{Ti}^{2}$} & -1.152 & 0.232 & $<0.0001^{\mathrm{a}}$ & $\mathrm{Q}^{2}$ & 0.711 & 0.216 & $0.0041^{\mathrm{d}}$ \\
\hline & & & & $\mathrm{Ti}^{2}$ & -0.956 & 0.216 & $0.0003^{\mathrm{a}}$ \\
\hline
\end{tabular}

${ }^{*} \mathrm{R}^{2}, 0.97 ; * * \mathrm{R}^{2} 0.98$, ${ }^{\mathrm{a}}$ Significant at $0.001 ;{ }^{\mathrm{b}}$ Not significant even at $0.05 ;{ }^{\circ}$ Significant at 0.05 ; ${ }^{\mathrm{d}}$ Significant at 0.01 


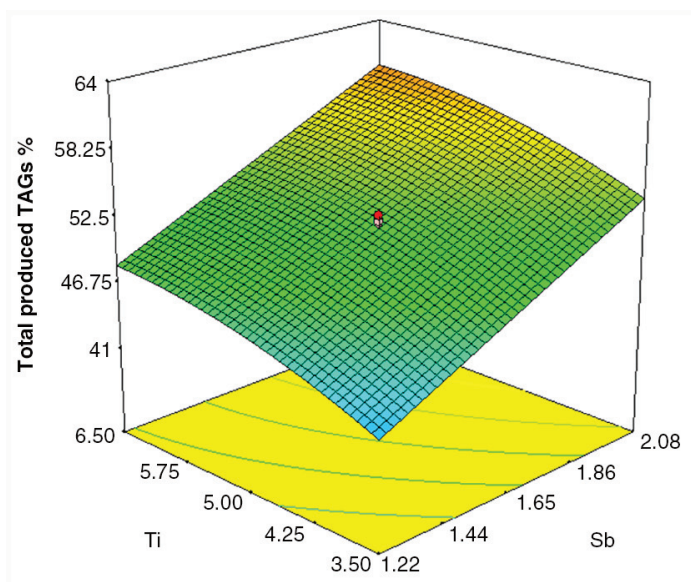

(a)

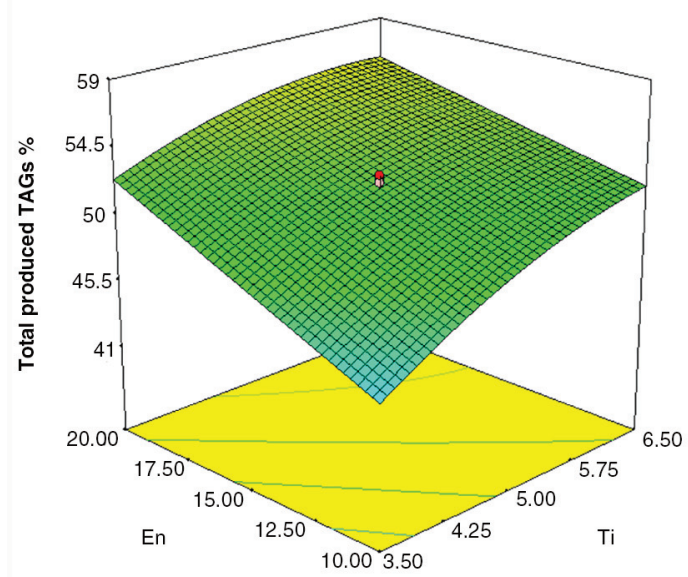

(c)

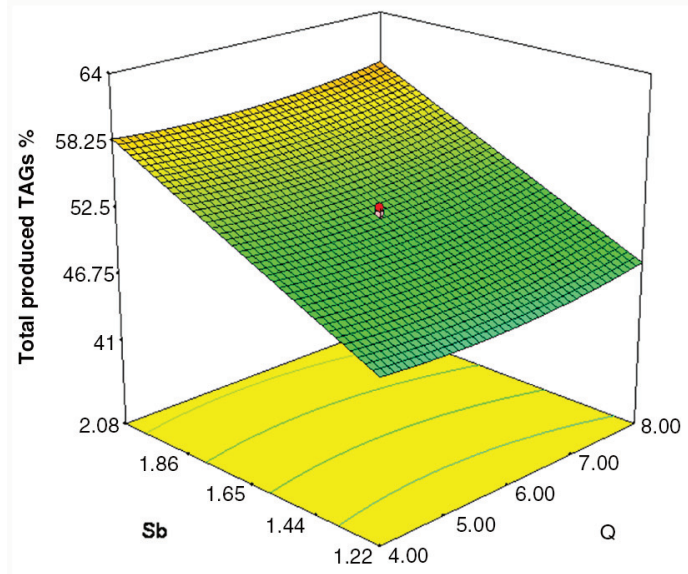

(e)

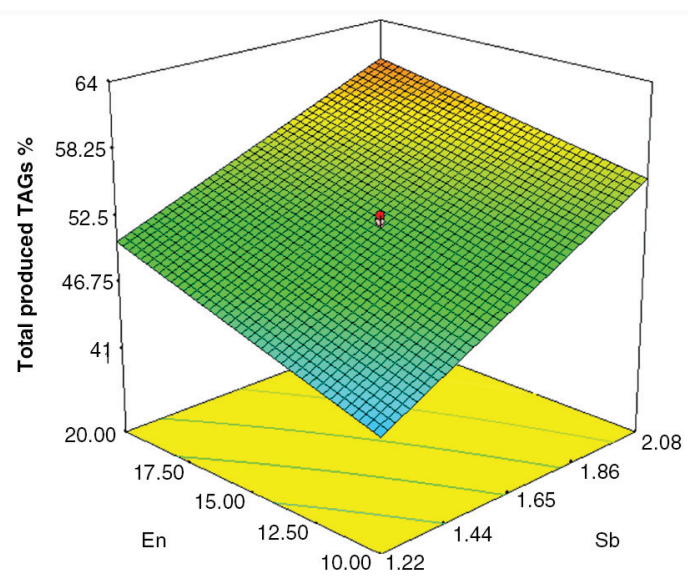

(b)

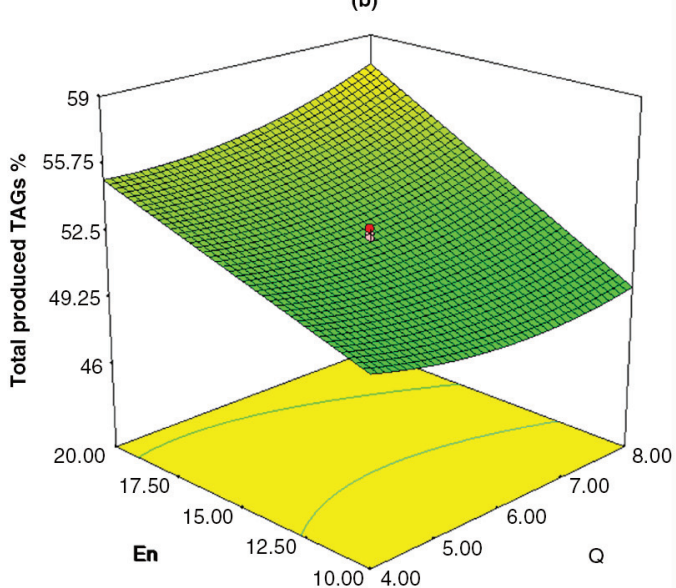

(d)

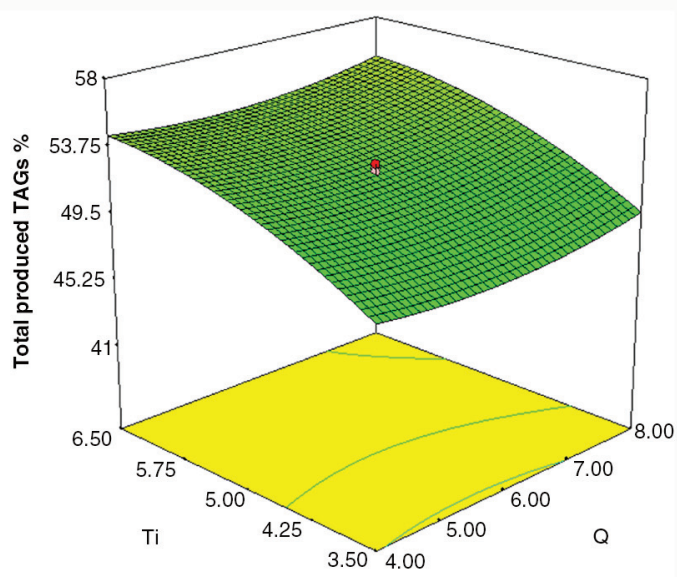

(f)

FIGURE 1. Response surface plots for total produced TAGs \%: (a) time vs. substrate molar ratio; (b) enzyme load vs. substrate molar ratio; (c) temperature vs. substrate molar ratio; (d) temperature vs. enzyme load; (e) time vs. enzyme load (f) time vs. temperature.

Figures 2(c) and 2(d) show the interactions between En*Ti and En*Q on the desired TAG (\%), respectively. Their effects were found similar to those of the total produced TAGs (\%). However, the interaction between $\mathrm{En} * \mathrm{Sb}$ was not found significantly effective on the synthesis of the desired TAGs in contrast to that of the total produced TAG $(\%)$. 


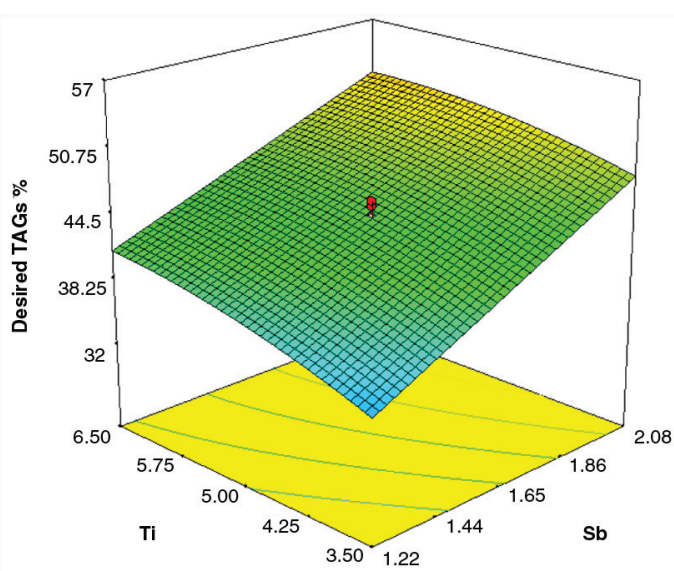

(a)

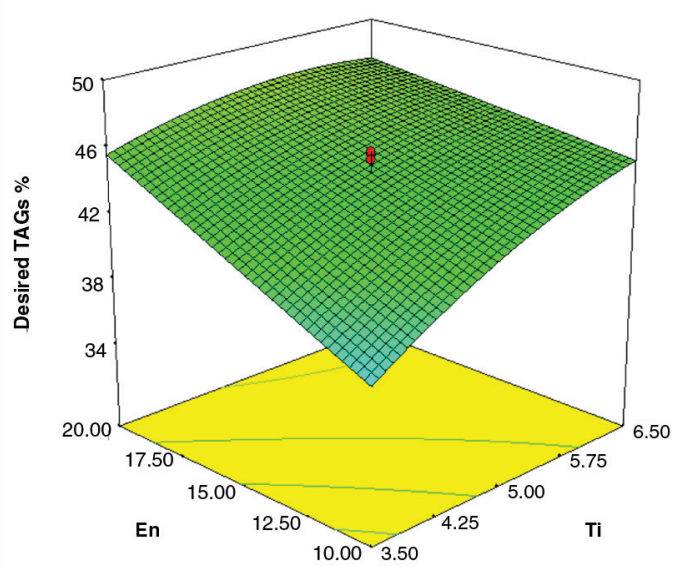

(c)

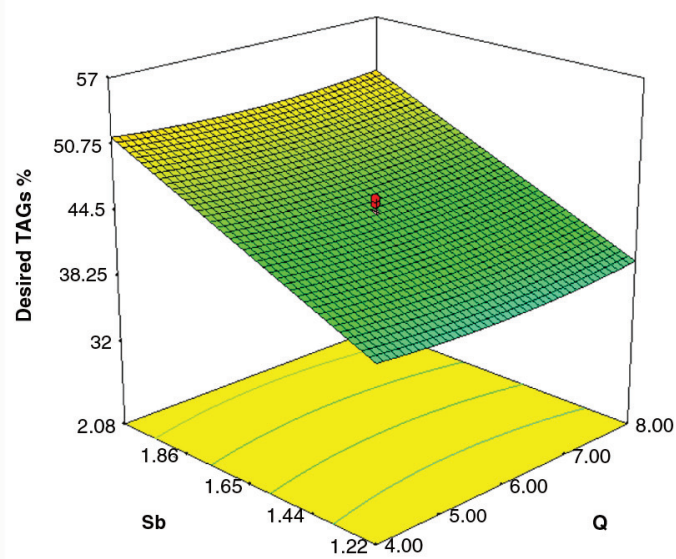

(e)

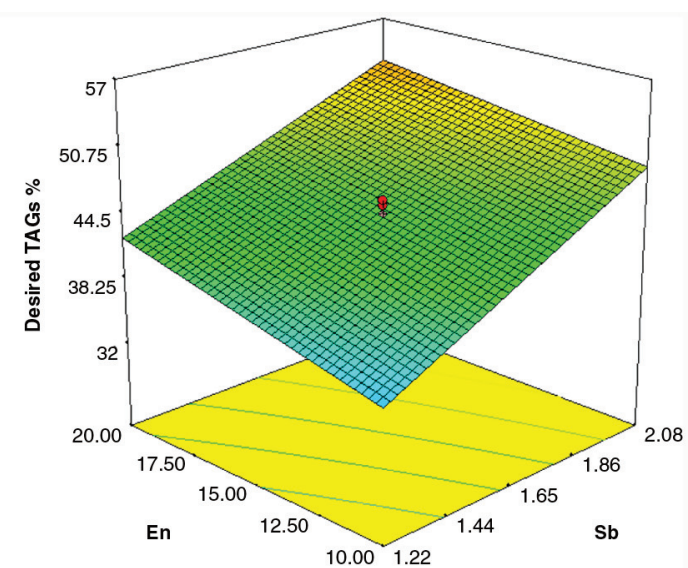

(b)

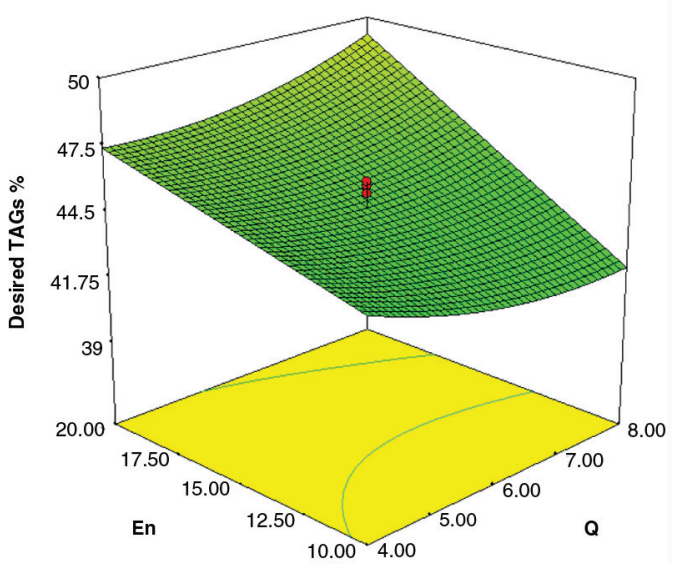

(d)

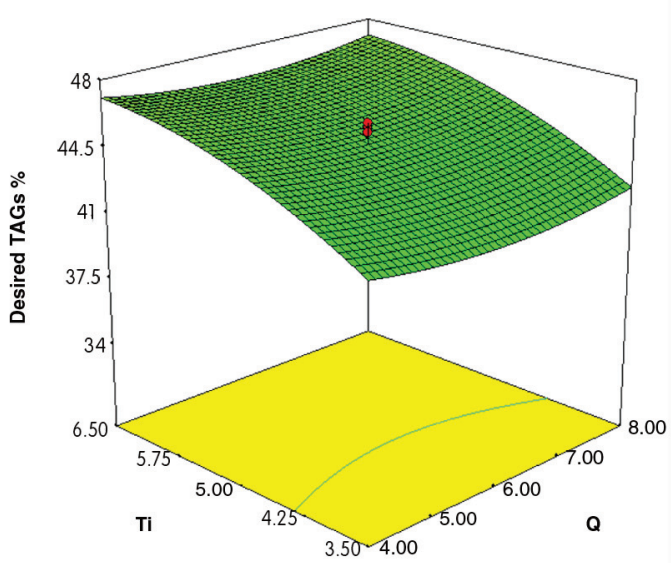

(f)

FIGURE 2. Response surface plots for produced desired TAGs \%: (a) time vs. substrate molar ratio; (b) enzyme load vs. substrate molar ratio; (c) temperature vs. substrate molar ratio; (d) temperature vs. enzyme load; (e) time vs. enzyme load (f) time vs. temperature.

\subsection{Optimization of reaction parameters}

The optimal conditions for the lipase catalyzed acidolysis reaction of TO with CA and PA were predicted using Design Expert Software. The desired
TAG (\%) and caloric value of the produced SL were evaluated to produce a targeted SL. The $\%$ of solid fat value by DSC was not included in the optimization processes even it was aimed to produce low calorie, spreadable SL. However, the $\%$ of solid fat 
TABLE 3. Solutions of optimum condition generated by design expert software

\begin{tabular}{lccccccccc}
\hline & \multicolumn{3}{c}{ Independent variables } & & \multicolumn{5}{c}{ Responses } \\
\cline { 2 - 3 } Solutions & $\mathbf{S b}^{\mathbf{a}}$ & $\mathbf{E n}^{\mathbf{b}}$ & $\mathbf{Q}^{\mathbf{c}}$ & $\mathbf{T i}^{\mathbf{d}}$ & & $\begin{array}{c}\text { Total produced } \\
\text { TAGs \% }\end{array}$ & Desired TAGs \% & Energy $\left(\mathbf{k j}^{-\mathbf{g}^{-1}}\right)$ \\
\hline 1 & 2.07 & 10.00 & 4.00 & 5.90 & & 58.90 & 52.23 & 38.96 \\
2 & 2.07 & 10.01 & 4.00 & 5.63 & & 58.44 & 51.84 & 38.96 \\
3 & 2.07 & 10.00 & 4.12 & 5.80 & & 58.63 & 51.95 & 38.96 \\
4 & 2.07 & 10.00 & 4.00 & 6.24 & & 59.39 & 52.63 & 38.97 \\
5 & 2.07 & 10.00 & 4.02 & 5.49 & & 58.15 & 51.59 & 38.96 \\
\hline
\end{tabular}

${ }^{a}$ Substrate mole ratio (mol/mol, Terebinth oil:Fatty acid 1:1.22-2.07); ${ }^{b}$ Enzyme load (wt \%, based on the amount of substrates); ${ }^{\mathrm{c}}$ Substrate flow rate $\left(\mathrm{mL} \cdot \mathrm{min}^{-1}\right) ;{ }^{\mathrm{d}} \mathrm{Time}(\mathrm{h})$

values by DSC was evaluated for the SL synthesized at optimum conditions. Table 3 shows the first five solutions predicted for the maximum synthesis of desired TAG and minimum energy under optimized conditions at which the enzyme load was set at its minimum value due to the cost consideration, while the other variables were set in the range of the studied values (Koh et al., 2010). The optimum conditions which satisfied the above requirements with high desirability $(0.86)$ would give $58.90(\%)$ total produced TAG, $52.23(\%)$ desired TAG and 38.96 $\mathrm{kj} / \mathrm{g}$ energy. The fatty acid and TAG compositions of the SL synthesized at optimum conditions and the TO are given in Tables 4 and 5, respectively. It was concluded that the target SL can be synthesized using lower amounts of substrate within the shorter reaction time in the PBR system compared to a previous study in which a batch process was performed (Koçak, et al., 2013).

\subsection{Caloric values of structured lipids}

The theoretical energy values of TO and the produced SL were calculated from the heat of combustion of their TAG species. Taguchi et al., (2001)

TABLE 4. Fatty acid composition of terebinth fruit oil and optimized structured lipid

\begin{tabular}{ccc}
\hline Fatty acid & Terebith fruit oil (\%) & Optimized SL (\%) \\
\hline $8: 0$ & - & 7.59 \\
$14: 0$ & - & - \\
$16: 0$ & 21.76 & 42.06 \\
$16: 1$ & 1.43 & - \\
$17: 0$ & - & - \\
$17: 1$ & - & - \\
$18: 0$ & 1.03 & 0.38 \\
$18: 1$ & 53.49 & 32.51 \\
$18: 2$ & 21.89 & 16.88 \\
$18: 3$ & 0.40 & 0.58 \\
$20: 1$ & - & - \\
\hline
\end{tabular}

reported that the energy value of an oil calculated theoretically was in agreement with the energy values measured by a bomb calorimeter. The theoretical energy value of TO was calculated as $39.53 \mathrm{kj} \cdot \mathrm{g}^{-1}$. The theoretical energy value for the produced SL is given in Table 1. The predicted energy value of SL suggested by the optimization process was $38.96 \mathrm{kj} \cdot \mathrm{g}^{-1}$. Under optimized

TABLE 5. TAG composition of terebinth fruit oil and optimized structured lipid

\begin{tabular}{lcc}
\hline TAG & Terebinth fruit oil (\%) & Optimized SL (\%) \\
\hline CLC & - & 1.10 \\
COC & - & 2.12 \\
CLL & - & 0.77 \\
COL & - & 2.33 \\
PLC & - & 8.06 \\
COO & - & 2.83 \\
POC & - & 14.54 \\
LLL & 2.20 & - \\
OLLn+PoLL & 1.21 & 1.73 \\
OLL+OLPo & 8.66 & 0.67 \\
PLL & 4.47 & 2.96 \\
OOL+PPLn & 14.43 & 1.35 \\
PLO+SLL & 12.98 & 9.12 \\
PoOP & 4.27 & - \\
PPL & 3.45 & 13.57 \\
OOO & 14.75 & 1.29 \\
OOP & 21.80 & 10.16 \\
PPO & 8.43 & 24.06 \\
PPP & 0.06 & 1.88 \\
SOO & 1.98 & 0.24 \\
POS & 1.03 & 0.86 \\
PPS & - & - \\
Unknowns & 0.27 & 0.34 \\
\hline : Capryc & &
\end{tabular}

C: caprylic acid, Ln: linolenic acid, L: linoleic acid, S: stearic acid, P: palmitic acid, O: oleic acid, Po: palmitoleic acid 
conditions, there was a $1.44 \%$ reduction in the caloric value of terebinth oil by incorporation of caprylic and palmitic acids.

\subsection{The percent of solid fat of structured lipids}

Table 6 shows the percentages of solid fat values of terebinth oil, some commercially available soft and hard margarine fat extracts, and the SL which was produced with the optimized process set-up. A margarine/spread should be spreadable at refrigerator temperature, keep its stability at room temperature and melt sharply at body temperature. Normally, these properties can be approximated by the amount of solid fat at 10,21 and $33{ }^{\circ} \mathrm{C}$ (List and King 2006). The $\%$ of solid fat of the produced SL was compared with that of commercial margarines and TO. It can be concluded that the $\%$ of solid fat values of the SL were significantly different compared to those of TO. Even if the \% of solid fat values of the SL were different than those of a particular margarine type, they are within the range of soft and hard margarines.

\subsection{Microstructure of structured lipids}

Figure 3 shows the crystal morphology of terebinth fruit oil, the fat phase of a commercially available soft margarine and the SL which produced at optimized reaction conditions. Microstructural differences exist in the fat crystal networks of TO, SL and margarine. While more loosely packed needle-like shape crystals were present in terebinth fruit oil, large symmetrical spherulite crystals were observed after interesterification. This could be due to the production of TAG structures such as COC,

TABLE 6. Percentage of solid fat values of the structured lipid and fat extracts of commercial margarines

\begin{tabular}{lcccc}
\hline & \multicolumn{4}{c}{ \% of solid fat by DSC } \\
\cline { 2 - 5 } Samples & $\mathbf{4 0}$ & $\mathbf{2 1}$ & $\mathbf{2 5}$ & $\mathbf{3 3}$ \\
\cline { 2 - 5 } & $\mathbf{1 0}$ & $0.42^{\mathrm{A}}$ & $0^{\mathrm{A}}$ & $0^{\mathrm{A}}$ \\
\hline $\mathrm{TO}^{\mathrm{a}}$ & $26.03^{\mathrm{A}}$ & $35.70^{\mathrm{B}}$ & $15.05^{\mathrm{B}}$ & $2.10^{\mathrm{A}}$ \\
$\mathrm{SL}^{\mathrm{b}}$ & $65.10^{\mathrm{B}}$ & $22.34^{\mathrm{C}}$ & $17.96^{\mathrm{C}}$ & $8.52^{\mathrm{B}, \mathrm{D}}$ \\
$\mathrm{A}^{\mathrm{c}}$ & $25.82^{\mathrm{A}}$ & $19.32^{\mathrm{C}}$ & $14.73^{\mathrm{B}, \mathrm{C}}$ & $6.27^{\mathrm{B}}$ \\
$\mathrm{B}^{\mathrm{d}}$ & $24.88^{\mathrm{A}}$ & $20.34^{\mathrm{C}}$ & $16.12^{\mathrm{B}, \mathrm{C}}$ & $6.27^{\mathrm{B}, \mathrm{D}}$ \\
$\mathrm{C}^{\mathrm{e}}$ & $24.69^{\mathrm{A}}$ & $26.50^{\mathrm{D}}$ & $21.11^{\mathrm{D}}$ & $11.23^{\mathrm{C}}$ \\
$\mathrm{D}^{\mathrm{f}}$ & $33.88^{\mathrm{C}}$ & $53.31^{\mathrm{E}}$ & $41.26^{\mathrm{E}}$ & $18.75^{\mathrm{C}}$ \\
$\mathrm{E}^{\mathrm{g}}$ & $69.13^{\mathrm{D}}$ & $52.68^{\mathrm{E}}$ & $34.47^{\mathrm{F}}$ & $9.09^{\mathrm{D}}$ \\
$\mathrm{F}^{\mathrm{h}}$ & $77.01^{\mathrm{E}}$ & $5{ }^{\mathrm{C}}$ & \\
\hline
\end{tabular}

${ }^{\mathrm{a}}$ Terebinth fruit oil; ${ }^{\mathrm{b}}$ Structured lipid produced at optimized conditions; ${ }^{\mathrm{c}, \mathrm{d}, \mathrm{e}, \mathrm{f}}$ Fat extracts of soft margarines; ${ }_{\mathrm{g}, \mathrm{h}}^{\mathrm{h}}$ at extracts of hard margarines, ${ }^{A-F}$ Means within each column with different letters are significantly $(P<0.05)$ different.
POC, and POP etc. by the incorporation of saturated fatty acids (caprylic and palmitic acid) into the TO. Figure 3 demonstrates that the SL contained a smaller number of large fat crystals than those of the fat phase of margarine where small spherulites were overlapped with each other in a denser network.

\subsection{Oxidative stability}

In this study, the DSC technique has been successfully applied to obtain the oxidative stability of terebinth fruit oil, a commercially available soft margarine and the produced SL. In this method, the thermal changes occurring during oxidation of the oil are recorded. A rapid increase in the amount of evolved heat is observed during the initiation of the oxidation reaction and it is recorded as induction time. The induction time of terebinth fruit oil, margarine and the SL were measured as 37.6, 22.6 and $53.8 \mathrm{~min}$, respectively. Generally, edible oils with higher degrees of unsaturation are more susceptible to lipid oxidation (Tan et al., 2002). However, terebinth fruit oil was found more resistant than margarine to oxidative deterioration, even though it contained a high percentage of unsaturated fatty acids such as oleic and linoleic acids. The possible reason for this could be high phenolic and tocopherol contents (Durmaz and Gökmen 2011). The higher percentages of unsaturated fatty acids with higher oxidative rancidity were also reported by Tan et al., (2002); Pardauil et al., (2011). The produced SL showed a higher induction time than terebinth fruit oil. This result implied that the incorporation of saturated fatty acids (CA and PA) into TO improved the stability of the oil.

\section{CONCLUSION}

Based on the central composite rotatable design, a quadratic polynomial model was obtained to predict the total produced TAG (\%)and desired TAG $(\%)$ for the acidolysis reaction of terebinth fruit oil with caprylic and palmitic acids. According to CCRD optimization, maximum desired TAG $(52.23 \%)$ with minimal caloric value $\left(38.96 \mathrm{kj} \cdot \mathrm{g}^{-1}\right)$ was obtained using a $10.0 \%$ enzyme load, $5.9 \mathrm{~h}$ reaction time, $4 \mathrm{~mL} / \mathrm{minsubstrate}$ flow rate and 1:3.1:2.07TO:PA:CA mole ratio. The melting characteristics and microstructure of the produced SL were found similar to those of commercial margarine fat extracts. The melting characteristics of the SL produced showed its suitability to be used as a spreadable fat. The produced SL showed the highest oxidative stability among the studied fats. 


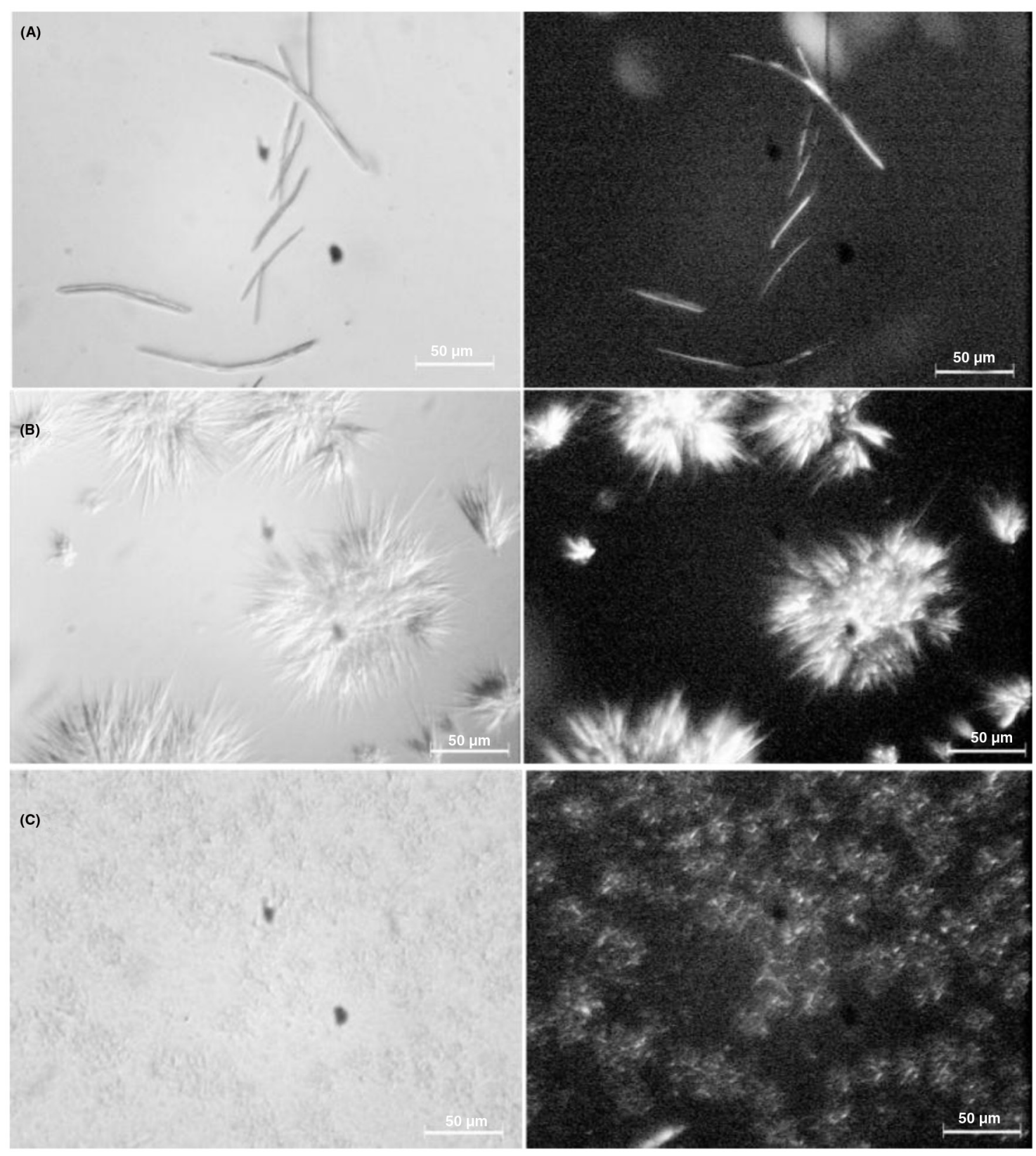

FIGURE 3. Polarized light micrograph grayscale images of (A) margarine (B) structured Lipid (C) terebinth oil.

\section{ACKNOWLEDGMENTS}

This research was supported by the Scientific Research Projects Governing Unit (BAPYB) of The University of Gaziantep.

\section{REFERENCES}

Agar IT, Kaska N and Kafkas S. 1995. Characterization of lipids in Pistacia species grown in Turkey. Acta Horticulturae. 419, 417-422. http://dx.doi.org/10.17660/ActaHortic.1995. 419.69 .
Ahmadi L, Wright AJ, Marangoni AG. 2008. Chemical and enzymatic interesterification of tristearin/ triolein-rich blends: Microstructure and polymorphism. Eur. J. Lipid Sci. Technol. 110, 1025-1034. http://dx.doi.org/10.1002/ ejlt.200800059.

AOCS (1993). Official methods and recommended practices of the American Oil Chemists' Society, 4th Edn. American Oil Chemists' Society Press, Champaigne, IL (USA).

Arifin N, Soo-Peng K, Long K, Chin-Ping T, Yusoff MSA, Oi-Ming L. 2012. Modeling and optimization of Lipozyme RM IM-catalyzed esterification of medium- and longchain triacyglycerols (MLCT) using response surface methodology. Food Bioprocess Technol. 5, 216-225. http://dx.doi. org/10.1007/s1 1947-010-0325-5. 
Çiftçi ON, Fadıloğlu S, Göğüs F. 2009a. Conversion of olive pomace oil to cocoa butter-like fat in a packed-bed enzyme reactor. Bioresour. Technol. 100, 324-329. http://dx.doi.org/ 10.1016/j.biortech.2008.05.035.

Çiftçi ON, Kowalski B, Fadıloğlu S, Göğüş F. 2009b. Effect of the addition of a cocoa butter-like fat enzymatically produced from olive pomace oil on the oxidative stability of cocoa butter. J. Food Sci. 74, 184-190. http://dx.doi. org/10.1111/j.1750-3841.2009.01128.x.

Dobarganes MC, Velasco J, Dieffenbacher A. 2000. Determination of polar compounds, polimerized and oxidized triacylglycerols, and diacylglycerols in oils and fats. Pure Appl. Chem. 72, 1563-1575. http://dx.doi.org/10.1351/pac200072081563

Durmaz G, Gökmen V. 2011. Changes in oxidative stability, antioxidant capacity and phytochemical composition of Pistacia terebinthus oil with roasting. Food Chem. 128, 410-414. http://dx.doi.org/10.1016/j.foodchem.2011.03.044.

Hamam F, Budge SM. 2010. Structured and specialty lipids in continuous packed column reactors: comparison of production using one and two enzyme beds. $J$. Am. Oil. Chem. Soc. 87, 385-394. http://dx.doi.org/10.1007/ s11746-009-1515-z.

Khodadadi M, AzizS, St-Louis R,Kermasha S. 2013. Lipasecatalyzed synthesis and characterization of flaxseed oilbased structured lipids. J. Funct. Foods. 5, 424 433. http:// dx.doi.org/10.1016/j.jff.2012.11.015.

Koh SP, Tan CP, Lai OM., Arifin N, Long K. 2010. Enzymatic synthesis of medium- and long- chain triacyglycerols (MLCT): optimization of process parameters using response surface methodology. Food Bioprocess Technol. 3, 288-299. http:// dx.doi.org/10.1007/s11947-008-0073-y.

Koçak D, Keskin H, Fadıloğlu S, Kowalski B and Göğüş F. 2011. Characterization of terebinth fruit oil and optimization of acidolysis reaction with caprylic and stearic acids. J. Am. Oil. Chem. Soc. 88, 1531-1538. http://dx.doi.org/10.1007/ s11746-011-1830-z.

Koçak Yanık D, Keskin H, Fadıloğlu S, Göğüs F. 2013. Acidolysis reaction of terebinth fruit oil with palmitic and caprylic acids to produce low caloric spreadable structured lipid. J. Am. Oil. Chem. Soc. 90, 999-1009. http://dx.doi.org/10.1007/ s11746-013-2250-z.

List GR, King JW (2006) Hydrogenation of lipids for use in food. In: Modifying Lipids for Use in Food. Eds. Gunstone FD. Wood head Publishing Limited and CRC Press, LLC (England) pp. 173-200.

Livesey G. 1984. The energy equivalents of ATP and the energy values of food proteins and fats. Brit. J. Nutr. 51, 15-28. http://dx.doi.org/10.1079/BJN19840005.
Osborn H, Akoh C. 2002. Structured lipids: Novel fats with medical, nutraceutical, and food applications. Compr. Rev. Food Sci. 1, 110-120. http://dx.doi.org/10.1111/j.15414337.2002.tb00010.x

Özcan M. 2004. Characteristics of fruit and oil of terebinth (Pistacia terebinthus L.) growing wild in Turkey. J. Sci. Food Agric. 84, 517-552. http://dx.doi.org/10.1002/jsfa.1632

Pardauil JJR, Souz LKC, Molfetta FA, Zamian JR, Rocha Filho GN, Da Costa CEF. 2011. Determination of the oxidative stability by DSC of vegetable oils from the Amazonian area. Bioresour. Technol. 102, 5873-5877. http://dx.doi.org/ 10.1016/j.biortech.2011.02.022.

Taguchi $H$, Nagao T, Watanabe H, Onizawa K, Matsuo N, Tokimitsu I, Itakura H. 2001. Energy value and digestibility of dietary oil containing mainly 1,3-diacylglycerol are similar to those of triacylglycerol. Lipids. 36, 379-382. http://dx.doi. org/10.1007/s11745-001-0731-7.

Tan CP, Che Man YB, Jinap S, Yusoff MSA. 2002. Comparative studies of oxidative stability of edible oils by differential scanning calorimetry and oxidative stability index methods. Food Chem. 76, 385-389. http://dx.doi.org/10.1016/ S0308-8146(01)00272-2.

Tieko Nassu, R, Guaraldo Gonçalves LA. 1995. Solid fat content determination: Comparison between pNMR and DSC techniques. Grasas Aceites. 46, 337-343. http://dx.doi.org/ 10.3989/gya.1995.v46.i6.949.

Topçu G, Ay M, Bilici A, Sarıkürkçü C, Öztürk M, Ulubelen A. 2007. A new flavones from antioxidant extracts of Pistacia terebinthus. Food Chem. 103, 816-822. http://dx.doi.org/ 10.1016/j.foodchem.2006.09.028.

Xu X, Balchen S, Høy C-E, Adler-Nissen J. 1998. Production of specific-structured lipids by enzymatic interesterification in a pilot continuous enzyme bed reactor. J. Am. Oil. Chem. Soc. 75, 1573-1579. http://dx.doi.org/10.1007/s11746-998-0096-6.

$\mathrm{Xu}$ X., Fomuso LB, Akoh CC. 2000. Modification of menhaden oil by enzymatic acidolysis to produce structured lipids: optimization by response surface design in a packed bed reactor. J. Am. Oil. Chem. Soc. 77, 171-176. http://dx.doi. org/10.1007/s11746-000-0027-3.

Yang T, Freukilde MB, Xu X. 2003. Applications of immobilized thermomyces lanuginosa lipase in interesterification. J. Am. Oil. Chem. Soc. 80, 881-887. http://dx.doi. org/10.1007/s11746-003-0789-7.

Zhao TT, Kim BH, Hong SI, Yoon SW, Kim CT, Kim Y, Kim IH. 2012. Lipase-catalyzed production of pinolenic acid concentrate from pine nut oil using a recirculating packed bed reactor. J. Food Sci. 77, 267-271. http://dx.doi.org/ $10.1111 / \mathrm{j} .1750-3841.2011 .02562 . x$. 